\title{
Morphological and complete mitogenomic characterisation of the acanthocephalan Polymorphus minutus infecting the duck Anas platyrhynchos
}

\author{
Huda Sarwar ${ }^{1,2}$, Wen-ting Zhao ${ }^{1}$, Caroline Jepkorir Kibet ${ }^{1}$, Jiljí Sitko $^{3}$ and Pin Nie ${ }^{1,4}$ (D) \\ ${ }^{1}$ State Key Laboratory of Freshwater Ecology and Biotechnology, Institute of Hydrobiology, Chinese Academy of Sciences, Wuhan, \\ China; \\ ${ }^{2}$ University of Chinese Academy of Sciences, Beijing, China; \\ ${ }^{3}$ Comenius Museum, Přerov, Czech Republic; \\ ${ }^{4}$ School of Marine Science and Engineering, Qingdao Agriculture University, Qingdao, China
}

\begin{abstract}
Morphological characteristics of the acanthocephalan Polymorphus minutus (Goeze, 1782), which was collected from the duck Anas platyrhynchos Linnaeus in the Czech Republic, are described. The mitochondrial (mt) genome of P. minutus was sequenced, with a total length of 14,149 bp, comprising 36 genes including 12 protein coding genes (PCGs), 22 transfer RNA (tRNA) genes and two ribosomal RNA genes ( $r r n L$ and $r r n S$ ). This genome is similar to the mt genomes of other syndermatan species. All these genes were encoded on the same DNA strand and in the same orientation. The overall nucleotide composition of the P. minutus mt genome was $38.2 \% \mathrm{~T}, 27.3 \% \mathrm{G}, 26.2 \% \mathrm{~A}$, and $8.3 \% \mathrm{C}$. The amino acid sequences of $12 \mathrm{PCGs}$ for $\mathrm{mt}$ genomes of 28 platyzoans, including $P$. minutus, were used for phylogenetic analysis, and the resulting topology recovers P. minutus as sister to Southwellina hispida (Van Cleave, 1925), and the two taxa form a sister clade to Centrorhynchus aluconis (Müller, 1780) and Plagiorhynchus transversus (Rudolphi, 1819), which are all species in the Palaeacanthocephala, thus supporting the monophyly of this class.
\end{abstract}

Keywords: Acanthocephala, Palaeanthocephala, morphological characteristics, mitochondrial genome, Polymorphida

Acanthocephalans are widely distributed obligate endoparasites with a total of about 1,300 species, and they use arthropods, including insects and crustaceans, as intermediate hosts. They can be found in all classes of vertebrates as final hosts, or occasionally as paratenic hosts (Bush et al. 2000, Amin 2013). Four classes, i.e. Archiacanthocephala, Eoacanthocephala, Palaeacanthocephala, and Polyacanthocephala, are recognised in terms of morphological traits such as the position of the lacunar system, the shape and size of the proboscis, the number of hooks, ligament sacs in females, cement glands in males, and even host taxonomy and ecology (Bullock 1969, Amin 1985, 1987, Crompton and Nickol 1985). In the Palaeacanthocephala, three orders, Echinorhynchida, Polymorphida and Heteramorphida, are recognised, with the highest species richness representing $65 \%$ of all acanthocephalan species, and a wide range of definitive hosts, including fish, birds and mammals, and malacostracans such as isopods and amphipods serving as intermediate hosts in this particular class of acanthocephalans (Near et al. 1998, Amin 2013, Goater et al. 2014, Gazi et al. 2016).
Polymorphus minutus (Goeze, 1782) in the Polymorphida of the Palaeacanthocephala is reported in aquatic birds from the order Anseriformes, and its larval stages are frequently recorded in marine- and freshwater gammarids, although a wide spectrum of definitive bird hosts is reported in other orders, such as Galliformes, Gruiformes, Alciformes, Charadriiformes, etc. (Crompton and Harrison 1965, Grabda 1971, Sulgostowska 1997, Pojmańska et al. 2007). Surprisingly, P. minutus is reported occasionally in other vertebrates, including raccoon, Procyon lotor (Linnaeus), European water-shrew, Neomys fodiens (Pennant), Arctic fox, Vulpes lagopus (Linnaeus), and muskrat Ondatra zibethicus (Linnaeus) (Mituch 1964, Crompton and Harrison 1965, Rausch et al. 1990, Piróg et al. 2018).

Mitochondrial (mt) genomes represent a useful source of data to test the monophyly of Palaeacanthocephala and Archiacanthocephala, and the validity of Syndermata (Acanthocephala and Rotifera) was confirmed through $\mathrm{mt}$ genome analyses (Pan and Nie 2013, Sielaff et al. 2016). Numerous studies have found that acanthocephalans in the Palaeacanthocephala and Archiacanthocephala are both 
monophyletic, as supported by morphological and molecular data (Monks 2001, Near 2002, García-Varela and Nadler 2006, Verweyen et al. 2011, Amin 2013, Gazi et al. 2016), but phylogenetic analysis based specifically on SSU rDNA data supported non-monophyly (Herlyn et al. 2003).

In this study, the ratio of the proboscis length to body length of $P$. minutus from Anas platyrhynchos Linnaeus was further studied, and its complete mt genome was sequenced for phylogenetic analyses. The mt genome was analysed and the phylogeny of acanthocephalans based on comparative analysis of available acanthocephalan complete mt genomes was constructed to provide a view on their phylogenetic relationships.

\section{MATERIALS AND METHODS}

\section{Specimen collection and morphological examination}

Specimens of Polymorphus minutus were collected from intestines of Anas platyrhynchos in Záhlinice, Czech Republic (49.2891N, 17.4798E). They were then washed with $0.9 \%$ saline and fixed in $95 \%$ alcohol for further use. For light microscopy, the specimens were stained with iron acetocarmine solution, destained in 70\% hydrochloric acid alcohol, dehydrated in a series of gradually increasing percentages of ethanol, 70\%, 80\%, 95\% and $100 \%$, cleared in clove oil and mounted in Canada balsam. Measurements were taken under $\mathrm{BH}-2$ Olympus microscope; length measurements are given before width, with the mean followed by the range. Specimens are deposited at the Institute of Hydrobiology, Chinese Academy of Sciences, Wuhan, Hubei Province, China (No. 201601).

\section{DNA extraction}

Prior to mtDNA extraction, parasites were washed thoroughly with water and then stored in $95 \%$ ethanol at $-80^{\circ} \mathrm{C}$, extracted by using Abcam Mitochondrial DNA extraction kit (ab65321; Abcam Trading, Shanghai), with suspended tissues in 1x Cytosol Extraction Buffer followed by treatment with Mitochondrial Lysis buffer and Enzyme Mix (lyophilised) according to manufacturer's instruction.

\section{Amplification and sequencing}

Initially, fragments of genes, including coxl, $\operatorname{rrnL}$, nad4 and $r r n S$, were amplified with degenerated primers. Based on these conserved regions, specific primers were designed to amplify long fragments using LA taq (TaKaRa) in a $25 \mathrm{ml}$ volume of reaction mixture containing $0.5 \mu \mathrm{M}$ of each primer $2.5 \mathrm{mM}$ of dNTP mixture, $0.8 \mu \mathrm{g}$ Template, TaKaRa LA Taq (5 units/ $\mu$ l) 0.25 $\mu 1$ and $10 \times$ LA PCR Buffer 11 ( $\mathrm{Mg}^{2+}$ plus) $2.5 \mu 1$ with the following amplification conditions for above four partial gene fragments: 94 ${ }^{\circ} \mathrm{C}$ for $2 \mathrm{~min} ; 35$ cycles of $94{ }^{\circ} \mathrm{C}$ for $30 \mathrm{~s}, 50{ }^{\circ} \mathrm{C}$ for $30 \mathrm{~s}$, annealing at $72{ }^{\circ} \mathrm{C}$ for $45 \mathrm{~s}$; extension at $72{ }^{\circ} \mathrm{C}$ for $10 \mathrm{~min}$, and the following conditions for long PCR products: initial denaturation at $94{ }^{\circ} \mathrm{C}$ for $3 \mathrm{~min}$; 34 cycles of denaturation at $94{ }^{\circ} \mathrm{C}$ for $30 \mathrm{~s}$, annealing at $60{ }^{\circ} \mathrm{C}$ for $30 \mathrm{~s}$; extension at $72{ }^{\circ} \mathrm{C}$ for $10 \mathrm{~min}$. PCR products were purified using omega gel Extraction Kit (omega) and ligated in pMD18-T vector (TaKaRa), then transformed into competent Escherichia coli strain top10. The recombinant clones were selected and sequenced using a Big Dye Terminators Cycle-Sequencing $\mathrm{Kit}(\mathrm{ABi})$ in both directions by primer walking method. Sequence data were anatomised using the seqMan program from DNASTAR (http://www.DNASTAR.com/). The complete $\mathrm{mt}$ genome sequence of $P$. minutus was submitted to the GenBank database with accession number MN646175. The sequence of primers and the size of PCR products are shown in Table 1.

\section{Gene annotation and alignment}

The protein-coding genes (PCGs) of P. minutus in the mt genome were analysed by NCBI ORF Finder. The two ribosomal RNA genes, $r r n \mathrm{~S}$ and $r r n \mathrm{~L}$, were confirmed based on the comparison of gene boundaries with other acanthocephalan mt genomes. The secondary structures of 22 tRNA genes were identified and drawn by tRNAScan-SE program (Lowe and Eddy 1997), DOGMA (Wyman et al. 2004), ARWEN (Laslett and Canbäck 2008) and MITOS (available at http://mitos.bioinf.uni-leipzig.de) (Bernt et al. 2013) and reconfirmed manually. Nucleotide composition data such as $\mathrm{A}+\mathrm{T}$ content were used for drawing graph in $\mathrm{R}$ 3.6.1. Relative synonymous codon usage (RSCU) for 12 PCGs of 10 acanthocephalans was drawn in ggplot2. BLASTn analysis was performed by using $\mathrm{mt}$ genome data of 28 platyzoans from

Table 1. PCR primers used for cloning mitochondrial genome of Polymorphus minutus (Goeze, 1782).

\begin{tabular}{|c|c|c|c|}
\hline Primer & DNA sequence $\left(5^{\prime}-3{ }^{\prime}\right)$ & Product size & Reference \\
\hline cox1F-661 & AGTTCTAATCATAARGATATYGG & \multirow{2}{*}{$680 \mathrm{bp}$} & \multirow{2}{*}{ Folmer et al. (1994) } \\
\hline cox1R-661 & TAAACTTCAGGGTGACCAAAAAATCA & & \\
\hline PMAcan-rrnLF & GACYGTRCTWAGGTAGCRTRATC & \multirow{2}{*}{$320 \mathrm{bp}$} & \multirow{2}{*}{ Gazi et al. (2015) } \\
\hline PMAcan-rrnLR & AWRDRATRATCCAACATCGAGGTA & & \\
\hline PMnad4-F & CCTAARGTKCATGTNGARGC & \multirow{2}{*}{$220 \mathrm{bp}$} & \multirow{2}{*}{ This study } \\
\hline PMnad4-R & GVAMTACHGAHGARTAHGCHAC & & \\
\hline PMrrnS-F & GATTAGAWACCYDKGTAR & \multirow{2}{*}{$280 \mathrm{bp}$} & \multirow{2}{*}{ This study } \\
\hline PMrrnS-R & TGACGGGCRATATGTACT & & \\
\hline cox1-rrnLF & GGAGGGGTAGGGTGAACTATG & \multirow{2}{*}{$2.1 \mathrm{~kb}$} & \multirow{2}{*}{ This study } \\
\hline cox1-rrnLR & CAAGGATGATCCAACATCGAGGTA & & \\
\hline rrnL-nad4F & GACTGTGCTAAGGTAGCATAATA & \multirow{2}{*}{$4.0 \mathrm{~kb}$} & \multirow{2}{*}{ This study } \\
\hline rrnL-nad4R & СТААССААСТСАССТСССССС & & \\
\hline nad4-rrnSF & TTTATGGCGGATACGGGGGGAG & \multirow{2}{*}{$5.2 \mathrm{~kb}$} & \multirow{2}{*}{ This study } \\
\hline nad4-rrnSR & АТССТАAССАAGTCССССТGCC & & \\
\hline $\operatorname{rrnS}-\operatorname{cox} 1 \mathrm{~F}$ & TAGATACCTGTGTAGTCCTATGAAA & \multirow{2}{*}{$3.5 \mathrm{~kb}$} & \multirow{2}{*}{ This study } \\
\hline rrnS-cox1R & GCAGCAGCCAAAACAGGAATA & & \\
\hline
\end{tabular}


Table 2. The species names and their mitochondrial genome GenBank accession numbers used in phylogenetic analyses in this study (29 species).

\begin{tabular}{|c|c|c|c|c|c|}
\hline Species name & Class & Accession No. & Species name & Class & Accession No. \\
\hline Platyhelminthes (15 species) & & & Syndermata (13 species) & & \\
\hline Benedenia seriolae & Monogenea & NC_014291.1 & Oncicola luehei & Acanthocephala & NC_016754.1 \\
\hline Benedenia hoshinai & Monogenea & NC_014591.1 & Macracanthorhynchus hirudinaceus & Acanthocephala & FR856886.2 \\
\hline Gyrodactylus salaris & Monogenea & NC_008815.1 & Leptorhynchoides thecatus & Acanthocephala & NC_006892.1 \\
\hline Gyrodactylus gurleyi & Monogenea & KU659806.1 & Echinorhynchus truttae & Acanthocephala & FR856883.1 \\
\hline Gyrodactylus nyanzae & Monogenea & MG970256.1 & Southwellina hispida & Acanthocephala & KJ869251.1 \\
\hline Microcotyle sebastis & Monogenea & NC_009055.1 & Polymorphus minutus* & Acanthocephala & MN646175 \\
\hline Polylabris halichoeres & Monogenea & NC_016057.1 & Centrorhynchus aluconis & Acanthocephala & KT592357.1 \\
\hline Fasciola hepatica & Trematoda & NC_002546.1 & Plagiorhynchus transversus & Acanthocephala & KT447549.1 \\
\hline Brachycladium goliath & Trematoda & 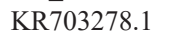 & Paratenuisentis ambiguus & Acanthocephala & FR856885.2 \\
\hline Fasciola gigantica & Trematoda & MH621335.1 & Pallisentis celatus & Acanthocephala & JQ943583.1 \\
\hline Paragonimus westermani & Trematoda & AF219379.2 & Polyacanthorhynchus caballeroi & Acanthocephala & KT592358.1 \\
\hline Taenia solium & Cestoda & NC_004022.1 & Philodina citrina & Rotifera & FR856884.1 \\
\hline Cladotaenia vulture & Cestoda & KU559932.1 & Rotaria rotatoria & Rotifera & NC_013568.1 \\
\hline Versteria mustelae & Cestoda & MK681866.1 & Arthropoda - outgroup & & \\
\hline Benedenia seriolae & Monogenea & NC_014291.1 & Limulus polyphemus & Merostomata & NC_003057.1 \\
\hline
\end{tabular}

* indicating the species whose mitochondrial genome was sequenced in the present study.

NCBI. The complete list of mt genomes and GenBank accession numbers are given in Table 2 .

\section{Phylogenetic analysis}

Phylogenetic analyses were conducted in PhyloSuite based on amino acid sequences of 12 PCGs for 28 platyzoans $\mathrm{mt}$ genomes including 11 acanthocephalan species along with the new mt genome of P. minutus, with Limulus polyfemus (Linnaeus) (Arthropoda) chosen as outgroup. Amino acid sequences for 12

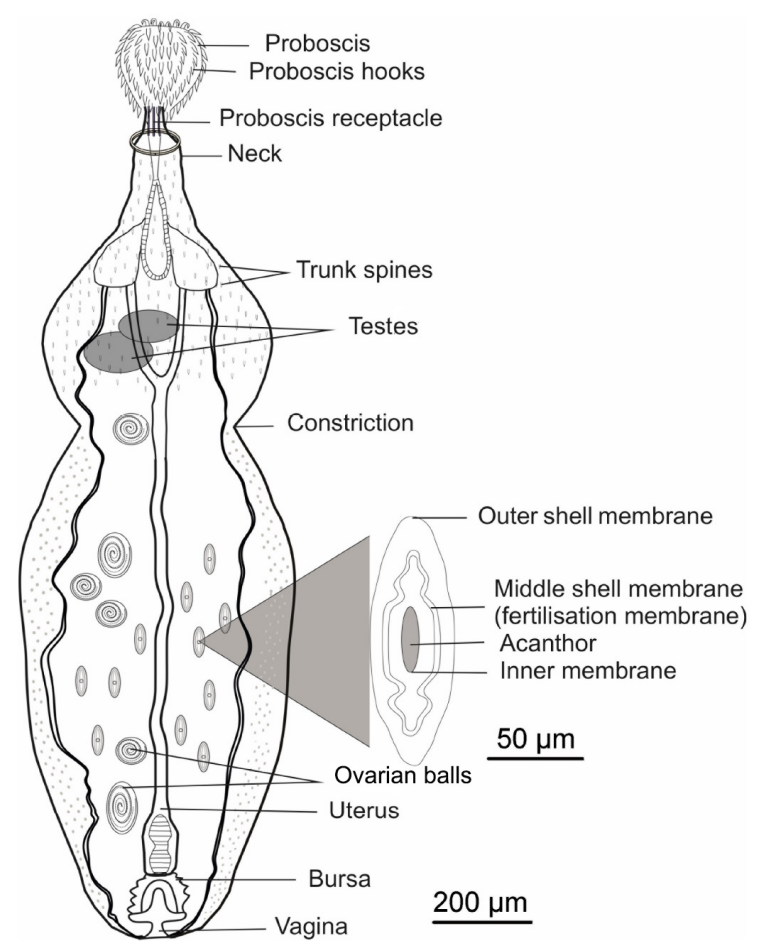

Fig. 1. Line drawing representation of whole Polymorphus minutus (Goeze, 1782) from Anas platyrhynchus Linnaeus. Elliptical egg with polar prolongations of middle membrane is showed via magnification.
PCGs were translated using MitoTool, and were aligned using the GINS-i algorithm performed with MAFFT (Katoh and Standley 2013). Alignments were refined using Gblocks (Talavera and Castresana 2007), concatenated in PhyloSuite (Zhang et al. 2018) and then analysed phylogenetically with Bayesian Interference (BI) and Maximum likelihood (ML) methods. ML analysis was performed via RAxML 7.0.3 using the MtArt model $(\mathrm{G}+\mathrm{I}+\mathrm{F})$ for all genes with 1,000 bootstrap replicates (Stamatakis 2006). $\mathrm{BI}$ analysis was performed by MrBayes 3.2.6 with parameters of Partition models for all genes $(\mathrm{LG}+\mathrm{I}+\mathrm{G}+\mathrm{F})$ and $2 \times 10^{7}$ generations with 0.25 burn-in fraction. Phylogenetic trees were visualised and annotated by iTOL.

\section{RESULTS AND DISCUSSION}

\section{Morphological description of Polymorphus minutus}

General: Parasites slightly oval, elongate, with prominent constriction observed at half body length, maximum width usually at middle of trunk. Anterior body part, before constriction, partially covered with numerous small spines 10-15 $\mu \mathrm{m}$ long. Proboscis oval, armed with 15 to 17 longitudinal rows of hooks, each with 8-10 hooks. Length of hooks smaller at base of proboscis. Proboscis receptacle much elongated and sac-like. Numerous eggs and ovarian balls present within trunk of mature females (Fig. 1).

Male $(\mathrm{n}=3)$ : Body 3.3-5.6 mm (4.1 mm) long, with maximum width $740-900 \mu \mathrm{m}(830 \mu \mathrm{m})$ at middle of trunk. Proboscis 194-280 $\mu \mathrm{m}(240 \mu \mathrm{m})$ long and 132-170 $\mu \mathrm{m}$ (153 $\mu \mathrm{m})$ wide; anterior hooks 50-90 $\mu \mathrm{m}(70 \mu \mathrm{m})$ long; medial hooks $60-80 \mu \mathrm{m}(70 \mu \mathrm{m})$ long; posterior hooks 50$60 \mu \mathrm{m}(55 \mu \mathrm{m})$ long. Neck 250-320 $\mu \mathrm{m}(284 \mu \mathrm{m})$ long and $100-150 \mu \mathrm{m}(110 \mu \mathrm{m})$ wide. Proboscis receptacle 500-770 $\mu \mathrm{m}(656 \mu \mathrm{m})$ in length and 103-131 $\mu \mathrm{m}(119 \mu \mathrm{m})$ in width (Fig. 1).

Female $(\mathrm{n}=20)$ : Body 2.4-4.6 mm (3.2 mm) long, with maximum width $630-900 \mu \mathrm{m}(749 \mu \mathrm{m})$ at middle of trunk. Proboscis 186-280 $\mu \mathrm{m}(228 \mu \mathrm{m})$ long and 110-170 $\mu \mathrm{m}$ (148 $\mu \mathrm{m})$ wide; anterior hooks 50-90 $\mu \mathrm{m}(72 \mu \mathrm{m})$ long; medial hooks 55-86 $\mu \mathrm{m}(73 \mu \mathrm{m})$ long; posterior hooks 


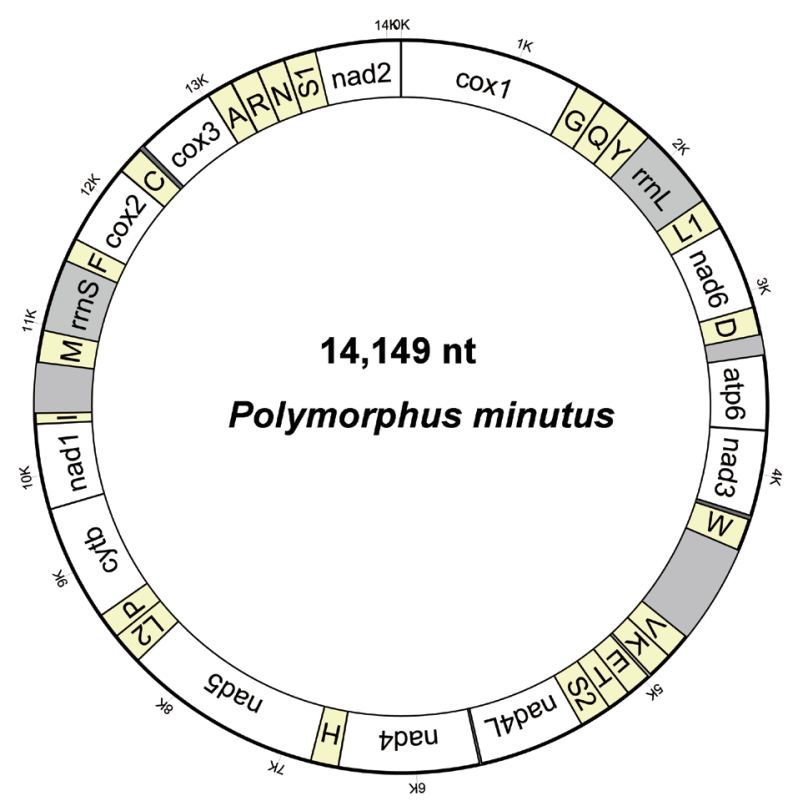

Fig. 2. Circular representation of the complete mitochondrial genome of Polymorphus minutus (Goeze, 1782) from Anas platyrhynchos Linnaeus.
40-70 $\mu \mathrm{m}(53 \mu \mathrm{m})$ long. Neck 220-320 $\mu \mathrm{m}(271 \mu \mathrm{m})$ long and 100-150 $\mu \mathrm{m}(110 \mu \mathrm{m})$ wide. Proboscis receptacle $550-850 \mu \mathrm{m}(669 \mu \mathrm{m})$ in length and 80-150 $\mu \mathrm{m}(120 \mu \mathrm{m})$ in width. Eggs 65-119 $\mu \mathrm{m}(96 \mu \mathrm{m})$ long and 22-35 $\mu \mathrm{m}(30$ $\mu \mathrm{m})$ wide (Fig. 1).

The description of the proboscis observed in the present study is compatible with that of worms obtained from Spatula querquedula (Linnaeus), Kashmir, India, characterised by Bhattacharya (2007). The length of anterior hooks of our specimens is consistent with that from specimens in waterfowl (length 67-79 $\mu \mathrm{m}$ in McDonald 1988), S. querquedula, Kashmir (length 58.5 $\mu \mathrm{m}$ in Bhattacharya 2007) and Procyon lotor (Linnaeus), Europe (length 52-66 $\mu \mathrm{m}$ in Piróg et al. 2018). In contrast, slight differences exist in the proboscis size, proboscis/ body length ratio, and hook length (Crompton and Harrison 1965, McDonald 1988, Bhattacharya 2007, Piróg et al. 2018). The ratio of the proboscis length to body length is most notable, with the ratio being $1: 10-21$ (females) and $1: 12-23$ (males) in our study, but $1: 6$ in P. minutus from P. lotor (see Piróg et al. 2018). Differences are also noticed when comparing measurements of the proboscis between the data obtained in the present study and worms in P. lotor,
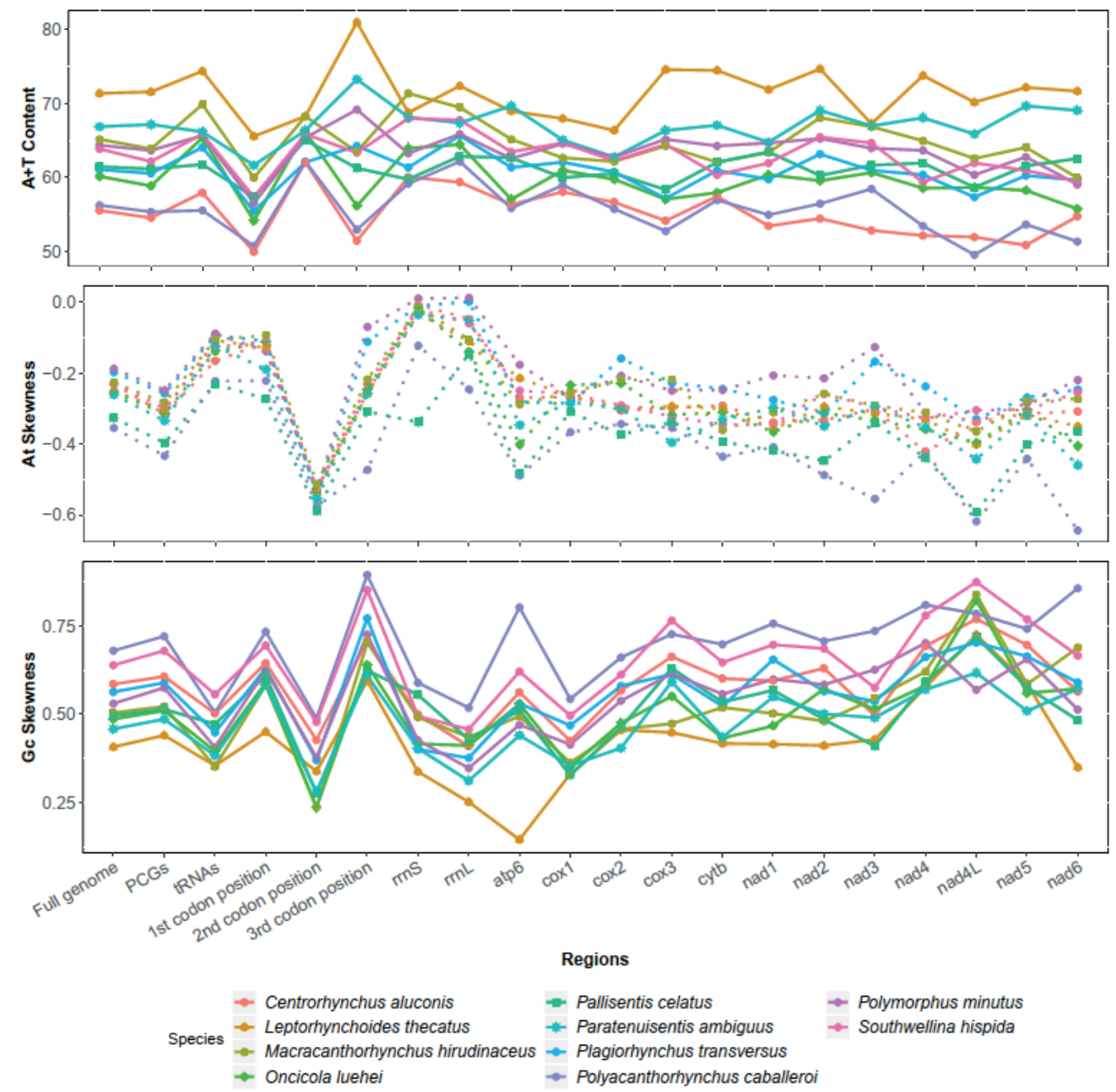

Fig. 3. A + T content and skewness of individual elements of 10 species of acanthocephalans. 
i.e., 410-480 × $150 \mu \mathrm{m}$ (Piróg et al. 2018). Furthermore, Piróg et al. (2018) did not observe decrease of hook size from the anterior to the posterior ones as observed in the present study.

\section{Mitochondrial genome of Polymorphus minutus}

The mt genome of $P$. minutus contains a total of 36 genes, including 12 PCGs (atp6, cytb, cox1-3, nad1-6 and nad4L), 22 transfer RNAs (tRNAs) and 2 ribosomal RNAs (rRNAs), which are on the same strand and encoded in the same direction. Gene content and gene order of PCGs are consistent with those in other $\mathrm{mt}$ genomes in acanthocephalans (Fig. 2) (Gissi et al. 2008). The length of mt genome in $P$. minutus, being $14,149 \mathrm{bp}$ long, falls within the size range of other acanthocephalans $(13,574-15,144 \mathrm{bp})$. The A $+\mathrm{T}$ content, which is $64.4 \%$ in P. minutus, is similar to that in $\mathrm{mt}$ genomes of other acanthocephalans, i.e., $63.9 \%$ in Southwellina hispida (Van Cleave, 1925) (14,742 bp in size) and $64.9 \%$ in Macracanthorhynchus hirudinaceus (Pallas, 1781) (14,282 bp), and 55.6\% in Centrorhynchus aluconis (Müller, 1780) (15,144 bp), even $71.46 \%$ in Leptorhynchoides thecatus (Linton, 1891) (13,888 bp). The nucleotide composition in P. minutus is biased towards $\mathrm{T}$, with higher T content $(39.8 \% \mathrm{~T})$ in 12 PCGs corresponding to relatively high frequency of T-rich codons (Fig. 3; Supplementary Table 1) (Steinauer et al. 2005, Gazi et al. 2012, Weber et al. 2013). Unequal usage of synonymous codon is contributing factor describing nucleotide composition toward $\mathrm{A}+\mathrm{T}$ content. Complete descriptions of $\mathrm{A}+\mathrm{T}$ content and AT skewness of acanthocephalans are compared for the first time. Nucleotide skewness of the $\mathrm{mt}$ genome (including all elements) in $P$. minutus exhibits a pattern as observed in $\mathrm{mt}$ genomes of other acanthocephalans (Fig. 3).

The 12 PCGs (excluding atp8) were distinguished in the $P$. minutus $\mathrm{mt}$ genome. The nad5 $(1,647 \mathrm{bp})$ and cox 1 (1,536 bp) are largest in size, while nad4L (270 bp) is the smallest. The usage of start and termination codons among acanthocephalan members varies greatly depending on genes, and there is no remarkable diagnostic pattern. The start codons, such as ATG, GTG, ATA, and stop codons, including TAG, TAA, T (incomplete) were observed in the mt genome of $P$. minutus. Truncated stop codons are common in other acanthocephalans and among bilaterian mitochondrial PCGs, which would probably be completed through post transcriptional polyadenylation (Ojala et al. 1981, Steinauer et al. 2005, Pan and Nie 2013, Gazi et al. 2012, 2016). Details of initiation and termination codons of 12 PCGs are shown in Supplementary Table 2.

The PCGs of the P. minutus mt genome are fundamentally encoded by T-rich codons (more than two Ts in a triplet), as for some other invertebrates, including acanthocephalans, nematodes, molluscs, dipteran insects and rotifers (Okimoto et al. 1992, Kurabayashi and Ueshima 2000, Lessinger et al. 2000, Steinauer et al. 2005, Min and Park 2009). In the $P$. minutus mt genome, valine (encoded by GTN; 15.99\%), leucine 2 (encoded by TTR; 12.96\%) and glycine (encoded by GGN; $11.44 \%$ ) were the most common, accounting for $40.4 \%$ of total amino acid components
(Supplementary Table 3). Valine (encoded by GTN) was most abundant (15.99\%) of total amino acid composition in the $P$. minutus mt genome, which is also observed in C. aluconis (17.67\%), Polyacanthorhynchus caballeroi Diaz-Ungria et Rodrigo, 1960 (19.68\%), Oncicola luehei (Travassos, 1917) (18.24\%), M. hirudinaceus (15.48\%) and S. hispida (16.46\%) (Supplementary Table 3, Supplementary Figure).

The $\operatorname{rrnL}$ gene is 917 bp in length flanked by $\operatorname{trn} Y$ and trnL1, similar to L. thecatus and O. luehei. The $r r n S$ gene is $581 \mathrm{bp}$ in length, and is situated between $\operatorname{trnM}$ and $\operatorname{trnF}$. Twenty two tRNA genes, ranging in size from 48 bp to 61 $\mathrm{bp}$, folded into cloverleaf-like secondary structure with the exception of $\operatorname{trn} S 1$ and $\operatorname{trn} Q$, which lacks a dihydrouridine

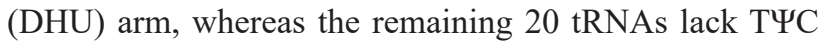
arm and hold a TV-replacement loop instead (Fig. 4), similar to those in other acanthocephalan $\mathrm{mt}$ genomes reported so far (Gazi et al. 2016).

\section{Pattern of the mitochondrial gene order}

The gene arrays of four species, S. hispida, P. minutus, C. aluconis and Plagiorhynchus transversus (Rudolphi, 1819) in the order Polymorphida are almost identical. Three tRNA genes, trn $V$, trnS1, trnS2, were translocated in P. minutus (Polymorphidae) and S. hispida (Polymorphidae), while only trnS2 was transferred in the mt genomes of P. minutus (Polymorphidae) and P. caballeroi (Polyacanthocephala). The results are contrary to the previous reports that same gene arrangements of $P$. caballeroi in relation to Pallisentis celatus (Van Cleave, 1928) reveal the sister relationship between the Eoacanthocephala and Polyacanthocephala (Fig. 5) (Gazi et al. 2016).

The specific gene order in species in the Polymorphida further reveals the monophyletic foundation concordant with the monophyletic cluster recovered from genome sequence analysis (Gazi et al. 2016). Three conserved gene clusters, nad2-cox1-trnG, trnY-rrnL-trnL2-nad6, and nad4L-nad4-trnH-nad5, exist among all members of the Lemniscea (Bdelloida + Acanthocephala), in spite of the striking difference in the arrangement of tRNAs (Fig. 5). The tRNA translocations are also observed in nematodes, molluscs, tunicates and crustacean arthropods (Boore et al. 2004, Tang and Hyman 2005, Kilpert and Podsiadlowski 2006, Vallès and Boore 2006, Stach et al. 2010, Hyman et al. 2011).

\section{Phylogeny of the Acanthocephala}

ML and BI methods were used to determine evolutionary relationship among the classes in the Acanthocephala by constructing mt genome phylogeny from amino acid sequences of 12 PCGs, although Echinorhynchus truttae Schrank, 1788 lacks nad4 and nad4L in the GenBank database, from 28 species belonging to the Platyzoa, including the newly sequenced $\mathrm{mt}$ genome of $P$. minutus. The generated trees with identical topologies had minor dissimilarities in supporting values for the Polymorphida (Fig. 6). The basic position of four classes in the Acanthocephala, was consistent with previously published phylogenetic studies: monophyletic Archiacanthocephala, the earliest 


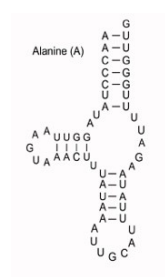

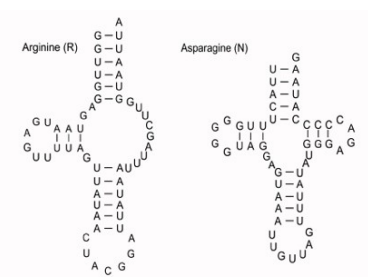

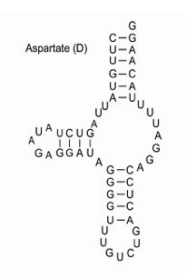

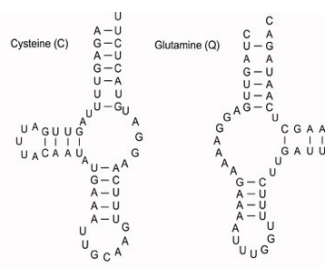

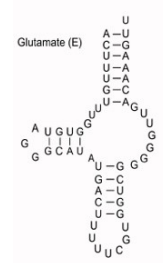

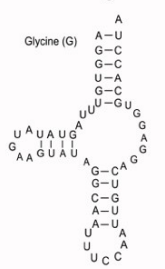

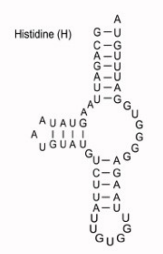

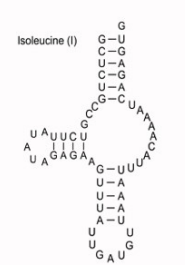

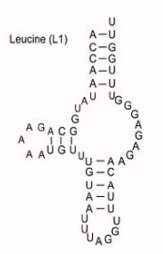

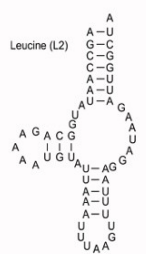

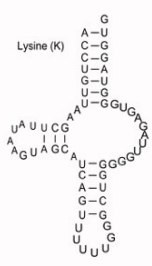

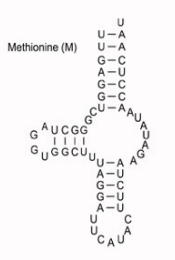

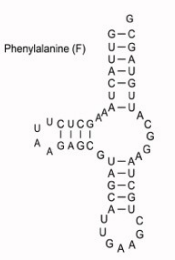

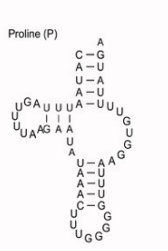

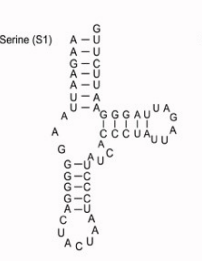

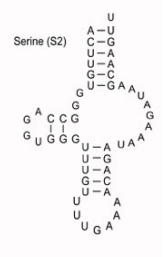

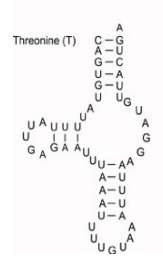

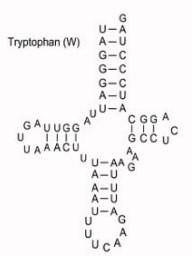

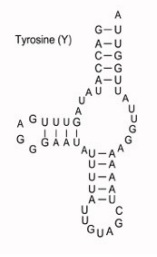

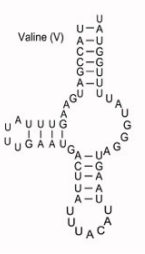

Fig. 4. The predicted secondary structure of 22 tRNAs of Polymorphus minutus (Goeze, 1782) from Anas platyrhynchos Linnaeus.

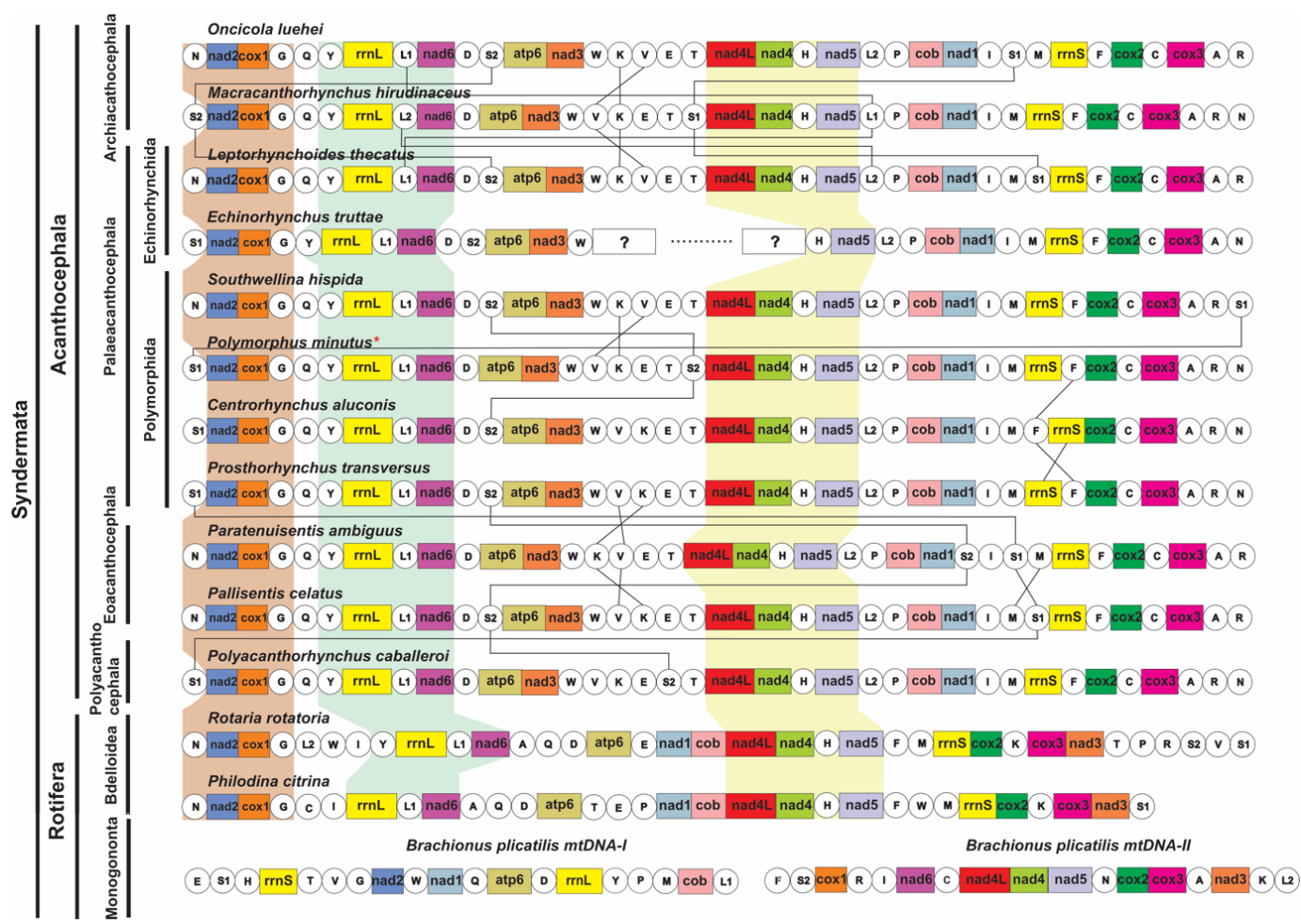

Fig. 5. Comparison of the linearised mitochondrial genome arrangements for 14 syndermatans, including 11 acanthocephalans and 3 rotiferan species. All genes are transcribed in the same direction from left to right. The asterisk (*) indicates the sequence of Polymorphus minutus (Goeze, 1782) from Anas platyrhynchos Linnaeus, which is newly characterised in this study. Boxes with (?) symbolise sequence regions with no gene annotation provided in previous studies. The shadowed regions highlighted in different colours represent common gene clusters. The tRNAs are shown in single letter abbreviations of an amino acid code. 


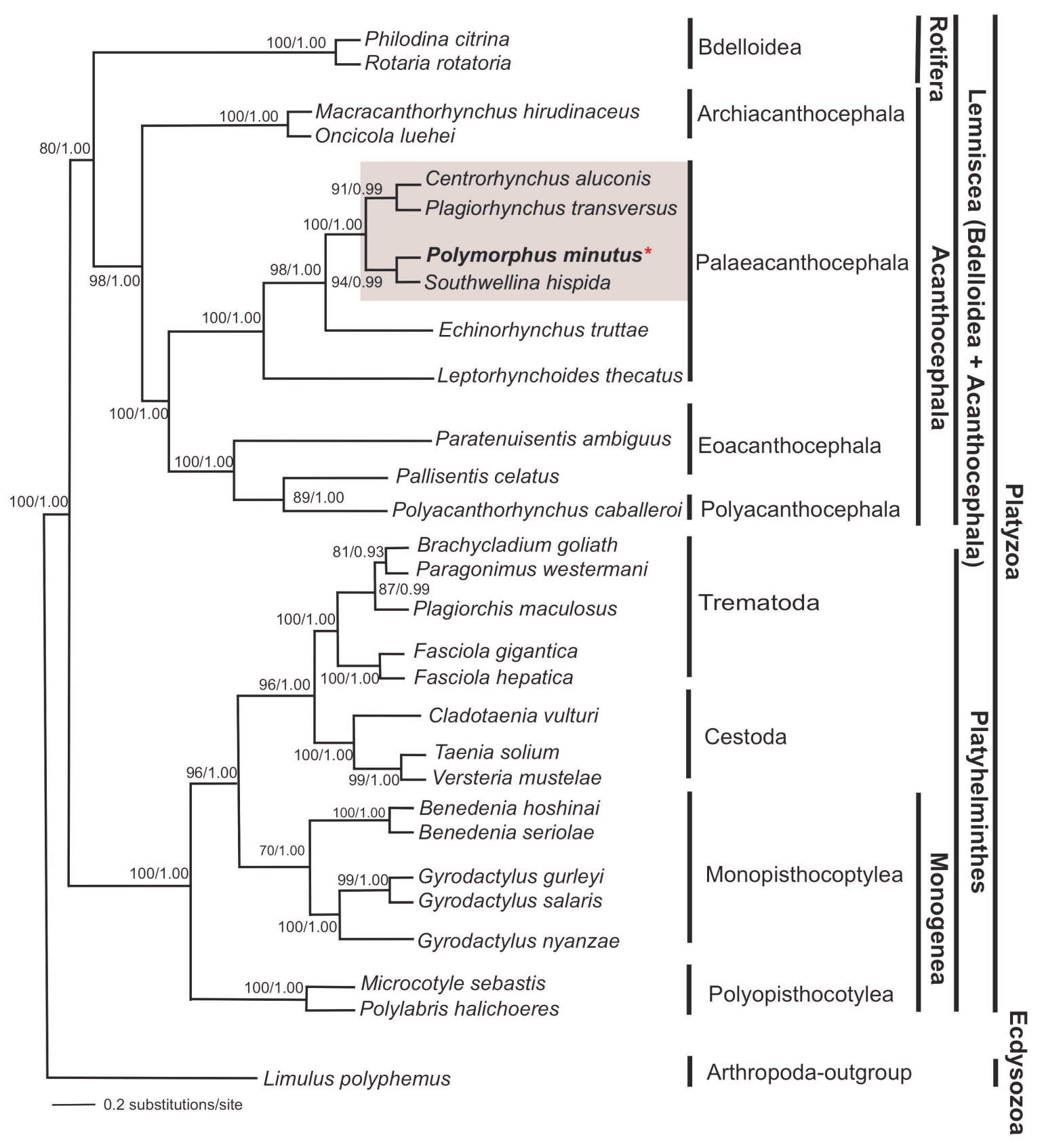

Fig. 6. Phylogenetic tree resulting from maximum likelihood for 12 protein-coding genes for 28 Platyzoan and 1 Arthropoda (outgroup) mitochondrial genomes. The asterisk (*) in red indicates the sequence of Polymorphus minutus (Goeze, 1782) from Anas platyrhynchos Linnaeus. The values indicated near the branches are the bootstrap percentages (BP) and Bayesian posterior probability (BPP) values for Maximum likelihood and Bayesian analysis, respectively.

branching clade of the Acanthocepala and monophyly of the Eoacanthocephala and Polyacanthocephala are rejected. It is notable to mention that the Palaeacanthocephala has close relationship with the Eoacanthocephala, which was concordant with previous findings based on morphological and molecular data such as SSU rDNA, LSUrDNA and mtDNA cox1 (García-Varela et al. 2000, 2002, García-Varela and Nadler 2005, 2006, Verweyen et al. 2011, Gazi et al. 2012, 2015, 2016). Polymorphus minutus clusters with $S$. hispida forming a sister clade to $C$. aluconis and $P$. transversus in the Palaeacanthocephala.
Acknowledgements. The research was carried out when Huda Sarwar received scholarships from the State Key Laboratory of Freshwater Ecology and Biotechnology, Institute of Hydrobiology, Chinese Academy of Sciences. The financial support was obtained from the China Agriculture Research System (CARS46), and from the State Key Laboratory of Freshwater Ecology and Biotechnology (2019FBZ02). Pin Nie also received fundings from a special top talent plan "One Thing One Decision (Yishi Yiyi) ([2018]27)" and the "First Class Fishery Discipline" programme [(2018)8] in Shandon Province, China. Thanks are also duo to Tomáš Scholz, Institute of Parasitology, Czech Academy of Sciences, for his kind help in obtaining the specimens. 


\section{REFERENCES}

Amin O.M. 1985: Classification. In: D.W.T. Crompton and B.B. Nickol (Eds.), Biology of the Acanthocephala. Cambridge University Press, London, pp. 27-71.

Амıм O.M. 1987: Key to the families and subfamilies of Acanthocephala, with the erection of a new class (Polyacanthocephala) and a new order (Polyacanthorhynchida). J. Parasitol. 73: 12161219.

Amin O.M. 2013: Classification of the Acanthocephala. Folia Parasitol. 60: 273-305.

Bernt M., Bleidorn C., Braband A., Dambach J., Donath A., Fritzsch G., Golombek A., Hadrys H., Jühling F., Meusemann K., Middendor M., Misof B., Perseke M., Podsiadlowski L., von Reumont B., Schierwater B., Schlegel M., Schrödl M., Simon S., Stadler P.F., Stöger I., Struck T.H. 2013: A comprehensive analysis of bilaterian mitochondrial genomes and phylogeny. Mol. Phylogenet. Evol. 69: 352-364.

Bhattacharya S.B. 2007: Handbook on Indian Acanthocephala. Zool. Surv. India, Kolkata, 225 pp.

Boore J., Medina M., Rosenberg L.A. 2004: Complete sequences of the highly rearranged molluscan mitochondrial genomes of the scaphopod Graptacme eborea and the bivalve Mytilus edulis. Mol. Biol. Evol. 21: 1492-1503.

Bullock W.L. 1969: Morphological features as tools and pitfalls in acanthocephalan systematics. In: G.L. Schmidt (Ed.), Problems in Systematics of Parasites. University Park Press, Baltimore, pp. 9-45.

Bush A.O., Jacqueline C.F., Esch G.W., Seed J.R. 2000: Parasitism: Diversity and Ecology of Animal Parasites. Cambridge University Press, Cambridge, $566 \mathrm{pp}$.

Crompton D.W.T., Harrison J.G. 1965: Observations on Polymorphus minutus (Goeze, 1782) (Acanthocephala) from a wildfowl reserve in Kent. Parasitology 55: 345-355.

Crompton D.W.T., Nickol B.B. 1985: Biology of the Acanthocephala. Adv. Parasitol. 5: 205-246.

Folmer O., Black M., Hoeh W., Lutz R., Vrijenhoek R. 1994 DNA primers for amplification of mitochondrial cytochrome c oxidase subunit I from diverse metazoan invertebrates. Mol. Mar. Biol. Biotechnol 3: 294-299.

García-Varela M., Cummings M.P., Pérez-Ponce de León G., Gardner S.L., LaClette J.P. 2002: Phylogenetic analysis based on $18 \mathrm{~S}$ ribosomal RNA gene sequences supports the existence of class Polyacanthocephala (Acanthocephala). Mol. Phylogenet. Evol. 23: 288-292.

García-Varela M., Nadler S.A. 2005: Phylogenetic relationships of Palaeacanthocephala (Acanthocephala) inferred from SSU and LSU rDNA gene sequences. J. Parasitol. 91: 1401-1409.

García-Varela M., Nadler S.A. 2006: Phylogenetic relationships among Syndermata inferred from nuclear and mitochondrial gene sequences. Mol. Phylogenet. Evol. 40: 61-72.

García-Varela M., Pérez-Ponce de León G., de la Torre P., Cummings M.P., Sarma SS., Laclette J.P. 2000: Phylogenetic relationships of Acanthocephala based on analysis of 18S ribosomal RNA gene sequences. J. Mol. Evol. 50: 532-540.

Gazi M., Kim J., García-Varela M., Park C., Littlewood D.T.J., PARK J.K. 2016: Mitogenomic phylogeny of Acanthocephala reveals novel class relationships. Zool. Scr. 45: 437-454.

GaZi M., Kim J., PARK J.K. 2015: The complete mitochondrial genome sequence of Southwellina hispida supports monophyly of Palaeacanthocephala (Acanthocephala: Polymorphida). Parasitol. Int. 64: 64-68.

Gazi M., Sultana T., Min G.S., Park Y.C., García-Varela M., NAdler S.A., PARK J.K. 2012: The complete mitochondrial genome sequence of Oncicola luehei (Acanthocephala: Archi- acanthocephala) and its phylogenetic position within Syndermata. Parasitol. Int. 61: 307-316.

Gissi C., Iannelli F., Pesole G. 2008: Evolution of the mitochondrial genome of Metazoa as exemplified by comparison of congeneric species. Heredity 101: 301-320.

Goater T.M., Goater C., Esch G. 2014: Parasitism: the Diversity and Ecology of Animal Parasites. Cambridge University Press, Cambridge, $497 \mathrm{pp}$.

Grabda J. 1971: [Catalogue of parasitic fauna of Poland. Part II. Parasites of cyclostomes and fishes.] PWN, Warszawa, 40 pp. (In Polish.)

Herlyn H., Piskurek O., Schmitz J., Ehlers U., Zischler H. 2003: The syndermatan phylogeny and the evolution of acanthocephalan endoparasitism as inferred from 18S rDNA sequences. Mol. Phylogenet. Evol. 26: 155-164.

Hyman B.C., Lewis S.C., Tang S., Wu Z. 2011: Rampant gene rearrangement and haplotype hypervariation among nematode mitochondrial genomes. Genetica 139: 611-615.

Katoh K., Standley D.M. 2013: MAFFT multiple sequence alignment software version 7: improvements in performance and usability. Mol. Biol. Evol. 30: 772-780.

Kilpert F., Podsiadlowski L. 2006: The complete mitochondrial genome of the common sea slater, Ligia oceanica (Crustacea, Isopoda) bears a novel gene order and unusual control region features. BMC Genomics 7: 241.

Kurabayashi A., Ueshima R. 2000: Complete sequence of the mitochondrial DNA of the primitive opisthobranch gastropod Pupa strigosa: systematic implication of the genome organization. Mol. Biol. Evol. 17: 266-277.

Laslett D., CANbäck B. 2008: ARWEN: A program to detect tRNA genes in metazoan mitochondrial nucleotide sequences. Bioinformatics 24: 172-175.

Lessinger A.C., Martins Junqueira A.C., Lemos T.A., Kemper E.L., da Silva F.R., Vettore A.L., Arruda P., Azeredo-Espin A.M. 2000: The mitochondrial genome of the primary screwworm fly Cochliomyia hominivorax (Diptera: Calliphoridae). Insect Mol. Biol. 9: 521-529.

Lowe T.M., EdDy S.R. 1997: tRNAscan-SE: a program for improved detection of transfer RNA genes in genomic sequence. Nucl. Acids Res. 25: 955-964.

MCDonald M.E. 1988: Key to Acanthocephala reported in Waterfowl. U.S. Department of the Interior, Fish and Wildlife Service. U.S. Fish and Wildlife Service, Washington, D.C., 692 pp.

MIN G.S., PARK J.K. 2009: Eurotatorian paraphyly: revisiting phylogenetic relationships based on the complete mitochondrial genome sequence of Rotaria rotatoria (Bdelloidea: Rotifera: Syndermata). BMC Genomics 10: 533.

Miтuch J. 1964: Beitrag zur Erkenntnis der Helmintenfauna der Gattung Neomys (Insectivora) in der Slovakei. Studia Helminthologia 1: 83-104.

Monks S. 2001: Phylogeny of the Acanthocephala based on morphological characters. Syst. Parasitol. 48: 81-116.

NEAR T.J. 2002: Acanthocephalan phylogeny and the evolution of parasitism. Integr. Comp. Biol. 42: 668-677.

Near T.J, Garey J.R., Nadler S.A. 1998: Phylogenetic relationships of the Acanthocephala inferred from 18S ribosomal DNA sequences. Mol. Phylogenet. Evol. 10: 287-298.

Ojala D., Montoya J., Attardi G. 1981: tRNA punctuation model of RNA processing in human mitochondria. Nature 290: 470-474.

Okimoto R., Macfarlane J.L., Clary D.O., Wolstenholme D.R. 1992: The mitochondrial genomes of two nematodes, Caenorhabditis elegans and Ascaris suum. Genetics 130: 471-498. 
Pan T.S., Nie P. 2013: The complete mitochondrial genome of Pallisentis celatus (Acanthocephala) with phylogenetic analysis of acanthocephalans and rotifers. Folia Parasitol. 60: 181-191.

Piróg A., Kuśmierek N., Popiolek M. 2018: The occurrence of avian acanthocephalan Polymorphus minutus (Goeze, 1782) in raccoons (Procyon lotor L.) introduced to Europe. Ann. Parasitol. 64: 249-252.

Pojmańska T., Niewiadomska K., Okulewicz A. 2007: [Parasitic helminths in Poland. Species, hosts, Terra Incognita.] Polish Parasitological Society, Warszawa, 18 pp. (In Polish, with summary in English.)

Rausch R.L., Fay F.H., Williamson F.S.L. 1990: The ecology of Echinococcus multilocularis (Cestoda: Taeniidae) on St. Lawrence Island, Alaska. II. Helminth populations in the definitive host. Ann. Parasitol. Hum. Comp. 65: 131-140.

Sielaff M., Schmidt H., Struck T.H., Rosenkranz D., Welch M.D.B., Hankeln T., Herlyn H. 2016: Phylogeny of Syndermata (syn. Rotifera): mitochondrial gene order verifies epizoic Seisonidea as sister to endoparasitic Acanthocephala within monophyletic Hemirotifera. Mol. Phylogenet. Evol. 96: 79-92.

Stach T., Braband A., Podsiadlowski L. 2010: Erosion of phylogenetic signal in tunicate mitochondrial genomes on different levels of analysis. Mol. Phylogenet. Evol. 55: 860-870.

Stamatakis A. 2006: RAxML-VI-HPC: maximum likelihood-based phylogenetic analyses with thousands of taxa and mixed models. Bioinformatics 22: 2688-2690.

Steinauer M.L., Nickol B.B., Broughton R., Ortí G. 2005: First sequenced mitochondrial genome from the phylum Acan- thocephala (Leptorhynchoides thecatus) and its phylogenetic position within Metazoa. J. Mol. Evol. 60: 706-715.

Sulgostowska T. 1997: [Catalogue of parasite fauna of Poland. IV. Parasites of birds. Acanthocephala.] Polskie Towarzystwo Parazytologiczne, Warszawa, 29 pp. (In Polish.)

Talavera G., Castresana J. 2007: Improvement of phylogenies after removing divergent and ambiguously aligned blocks from protein sequence alignments. Syst. Biol. 56: 564-577.

TANG S., Hyman B. 2005: Rolling circle amplification of complete nematode mitochondrial genomes. J. Nematol. 37: 236-241.

VALLÈs Y., Boore J.L. 2006: Lophotrochozoan mitochondrial genomes. Integr. Comp. Biol. 46: 544-557.

Verweyen L., Klimpel S., Palm H. 2011: Molecular phylogeny of the Acanthocephala (class Palaeacanthocephala) with a paraphyletic assemblage of the orders Polymorphida and Echinorhynchida. PLoS One 6: e28285.

Weber M., Wey-Fabrizius A.R., Podsiadlowski L., Witek A., Schill R.O., Sugar L., Herlyn H., Hankeln T. 2013: Phylogenetic analyses of endoparasitic Acanthocephala based on mitochondrial genomes suggest secondary loss of sensory organs. Mol. Phylogenet. Evol. 66: 182-189.

WyMAN S.K., JANSEN R., BoORE J. 2004: Automatic annotation of organellar genomes with DOGMA. Bioinformatics 20: 3252 3255.

Zhang D., Gao F.L., Li, W.X., Jakovlić I., Zou H., Zhang J., WANG G.T. 2018: PhyloSuite: an integrated and scalable desktop platform for streamlined molecular sequence data management and evolutionary phylogenetics studies. Mol. Ecol. Resour. 20: 348-355.

Cite this article as: Sarwar H., Zhao W., Kibet C.J., Sitko J., Nie P. 2021: Morphological and complete mitogenomic characterisation of the acanthocephalan Polymorphus minutus infecting the duck Anas platyrhynchos. Folia Parasitol. 68: 015. 